\title{
The Degree of the Faculties' Practice towards Students' Academic Counseling at Jordanian Universities
}

\author{
Dr. Ahmad M. Thawabieh \\ Department of Educational Psychology, Faculty of Educational Sciences, Tafila Technical University (TTU) \\ E-mail:ahmadthawabieh@yahoo.com \\ Dr. Atallah A. Al- roud
}

Department of Curricula and Instruction, Faculty of Educational Sciences, Tafila Technical University (TTU)

E-mail: atallah_roud@yahoo.com

\begin{abstract}
Academic counseling is considered as one of the most important factors of students instructional success. Since it orient students to the right direction of the university success and help them to face all academic challenges, especially students with learning disabilities. This study aimed to investigate the extent of the faculties commitment at Jordanian universities towards academic counseling and the factors affecting that.
\end{abstract}

Keywords: Education, School, Counseling, University, Student

\section{Introduction}

A university is considered as a productive establishment that provides generations with knowledge and develops them socially, scientifically, culturally...etc. It could be upheaded by three elements: students, faculties and the administrative staff, where the proficient instructor is the most important element (Sahlawy, 1992). Over the past few decades, education administrators and conscientious academic advisors have put great efforts to meet the needs and concerns of students to deliver optimum student satisfaction (Hendey, 1999).

Since a student is one of the elements of a university, he has to be given more attention especially in the beginning of joining a university. He will face a new environment with different systems than schools. The credit hour system, withdrawal, dropping, prerequisites of subjects, cumulative average, social relationships....etc, are all problems for a student so they need help from the academic counselor to guide and direct him.

Rickinson (1998) stated that new knowledge and experience in the university challenge students' development; at the same time the learning process in the university also brings a risk of temporary loss of balance which can result in psychological distress. Ismail (1983) Indicated that a university stage is completely different from the previous stages in system and the way of studying, and since it is the essential stage in a student's life, he needs counseling to help him understand the system of studying in a university.

Students may feel more relaxed while sharing with their counselor about the personal, psychological issues and all other academic issues. Although a majority of the faculties are aware that the intellectual development of students may vary, sometimes they may fail to approach the course content as desired (Brown, 2003).

It could be noticed that students with low average and who do not succeed are affected psychologically which could be reflected on their social relationships. Maxwell (1979) found that high-risk college students who do not succeed have made a poorer adaptation to the college environment, have less clearly defined aspiration are less committed to their goals, are less willing to study hard, and have weaker interpersonal skills and support. Academic counseling is considered as a behavioral system designed to interact with the instructional system in order to achieve the goals of instructional and learning process. It also aims to develop and improve the comprehensive instructional process. The academic counseling from staff member to the student should be based on appropriate solutions and alternatives for of students' problems. King (1993) showed that the advantages of academic counseling offer freedom to the student which leads to self-confidence and satisfies his interests.

Gudep (2007) concluded the following suggestions for the successful academic counseling: First counselors have to stop complaining which means that academic counselors may need to accept the students as part of the college/university population and may also make efforts to move on. Complaining and criticizing students (advisees) can demean academic advisors' morale and motivation to help those deserving group of advisees who may need an immediate intervention. Keeping the complaints to a minimum will create a congenial academic advising climate in the college campus. Second, change the delivery of service: the students may need more individualized attention and therefore herding them into large groups may not be effective. Using smaller groups or individual sessions to reach a 
diverse set of advisees may yield the desired results. If there is a lack of staff to keep up with demands, using peer advisers for support is emerging as a major option by many advisors. In addition to this, using more visuals may prove to be effective in reaching the advisees at the under graduate levels. Some advisees may take one of every flyer and seldom read any of the information on them. In these cases, using video presentations may stimulate interest and help them answering some questions before they sit across the desk of the academic advisor. A simple welcome video or PowerPoint presentation may work well. Third teach life skills

Since decision-making skills and self-advocacy skills may be lacking in undergraduate students, advisors may need to take an active role in teaching these skills. If this is not done effectively, the same advisees may be back next semester, probably with the same set of questions. Although advisees may be in the need of all the crucial information, promoting critical-thinking strategies to encourage them to make their own decisions may go a long away in orienting them towards academic advising goals. At this juncture the advisor may need to dig deep to find the relevant counselor skills, which may reduce the confusion of advisees. Finally be honest with students Being honest with the students on issues like academic policies, rules of promotion, scholarship avenues and placement opportunities plays a vital role in creating a positive image about the academic advising systems. There may exist a bunch of students who feel pressurized, while coming to a college for economic, social, or professional reasons and may sometimes seek a solace in the academic adviser on various academic and nonacademic issues.

\section{Review of Studies}

For the important role of the academic counseling many universities around the world established centers for counseling and many studies were conducted in this area. Isakson and Call (1991) found that student on academic warning who made contact with counselors showed greater improvement in grade point average (GPA) than students who did not make contact with counselors. Rickinson (1998) found that students who attended counseling appeared to be better equipped to adjust to the social and academic demands of the university environment. Nosanowi, Hage, and Levin (2000) found that group counseling can promote psychological health of college students from divorced families. Such counseling might reduce the long-term effect of being a child of a divorced family, by providing participants with life skills and the capacity for gaining control over their lives. Komiya, Good. and Sherrod.(2000) showed that counseling in external expression of emotion and the internal experiencing of strong emotion produces uncomfortable feelings, especially in certain cultural groups such as some Asian cultures. According to Light (2001), students who interact with faculty members will have fewer difficulties in orienting themselves towards the university curriculum.. Whelley et al (2003) stated that peer advising relationships are helpful for students with disabilities and slow learning skills. The results of Aluede, Imhonde, Eguavoen (2006) study revealed that irrespective of students' residential status, gender, age and relationship status, the students ranked time-management as the most pressing counseling need. This was followed in this order: drug concerns, family problems, career needs, relationship problems, finance, sexual harassment, academic ability, personality types, anxiety/depression, differential treatment and serf-evaluation. The results further indicated among others that female students were more in need of financial counseling than their male counterparts. Gudep (2007) investigates the UAE undergraduate students' attitude towards the issue of academic advising and tests whether a significant difference exists between the attitudes of three types of respondents chosen for this study. An instrument for measuring the attitudes of the students towards academic advising is developed. A sample of size of 482 students is chosen and a research framework is constructed to extract relevant factors affecting students' attitudes towards academic advising. The analytical results of t-test revealed that there is no significant difference between male and female respondents towards mobile advertising.

\section{Importance of the study}

The significance of the study emerged from the fact that it concentrates on the field of learning in universities and deals with an important sector of a society who is in need of guidance and direction, and to investigate the degree of the faculties' practice in counseling students in Jordanian universities, The researchers hope that they can find out results which may help the faculties in Jordanian universities understand their functional role in counseling their students.

\section{The Problem of the Study}

Academic counseling is one of the essential majors needed for university students. More precisely, the study aimed to answer the following questions:

1- What is the degree of the faculties' practice in counseling students at Jordanian universities?

2- Are there any statistically significant differences $(\alpha \leq 0.05)$ in the degree of the faculties practice in counseling students attributed to the type of college? 


\section{Abbreviations}

GPA: grade point average.

TTU: Tafila Technical University

ARD: Administration and Registration Directorate.

\section{Limitations of the study}

The present study was applied only on staff members at Tafila Technical University (TTU) during the 1st semester 2009.

\section{Methodology}

\subsection{Population and sample of study}

\subsubsection{Population of the study}

The researchers selected Tafila Technical University as a representative of the study population; since it is easy to reach and it isn't different from other universities in Jordan. So the population of the study consisted of all faculties at Tafila Technical University. (Table 1).

\subsubsection{Study Sample}

The sample of the study was a random sample consisted of (34) faculty members which forms (25.15\%) (Table 2).

\section{Method}

The researchers designed a questionnaire using their experience and the related literature. Then validity of the questionnaire was checked by using expert judgments, and its reliability was checked by using internal consistency (cronbach $\alpha$ equation), it was (0.89). The final form of the questionnaire was consisted of (15) items assess the degree of the faculties' practice in students' academic counseling, all items were positively oriented.

\section{Results}

The researchers wanted to answer the following two questions:

Question 1: what is the degree of faculties' practice in counseling students in Jordanian universities?

To answer this questions the researchers used descriptive statistics, and it was found that the faculties highly contributed in students' academic counseling, since the average for all items was (3.84) and according to likert scale this refers to a high point of the scale. It was also found that the highest academic counseling activities for the faculties' practice were:

Motivating achievers (4.81 average).

Following up the subject schedule for each semester (4.788 average).

Following up all changes which take place on instructional programs (4.55 average).

Introducing counseling to students relating to their methods of study (4.29 average).

Whereas the least activities practiced by faculties in counseling students were: communicating with parents to solve their sons academic problems (2.17 average), filing students academic record ( 2.9 average), scheduling adequate time for meeting with student (3.48 average).Table(3) represent these results.

Question 2: Are there any statistically significant differences $(\alpha \leq 0.05)$ in the degree of faculties' practice in counseling students attributed to the type of college and gender?

To answer this question 2-WAY ANOVA was used and it was found that there is no statistically significant differences attributed to type of college( humanistic or scientific) and gender or to the interaction between them.(table 4 ) represent these results.

The researchers added an open ended question by which the staff members could add any notes may not be covered in the questionnaire items, according to that they added the following:

Faculties try to solve students' problems to help them to finish the study plan requisites and graduate from the university.

Most students were not convinced with studying at TTU, and they like to study in other Jordanian Universities.

\section{Discussion}

The study indicated that staff members were highly participated in counseling students and this may be due to their high commitments to the university and may be resulted from work community inside the university since it is a newly established university (2005) with a small number of students (5000 students). 
The results also indicated that most staff members have low communication with the parents of the students and this could be explained by the fact that those students are adult people and they have to depend on themselves to solve their problems. The study found that most staff members haven't a counseling file for each student since there are such files in the Administration and Registration Directorate (ARD), although the researchers think that it is not enough and they are in need of more information about the students than the (ARD) file.

\section{Recommendations}

The researchers recommend that more studies were needed to predict other factors affecting academic counseling like staff member rank, another type of studies were also needed to investigate student's satisfaction about Studying at Tafila Technical University.

\section{Conclusions}

From the study results we could conclude that: faculties were highly involved in counseling students.

\section{References}

Aluede, O. Imhonde, H. \& Eguavoen.A. (2006). Academic, career and personal needs of Nigerian university students. Journal of Instructional Psychology. [Online] Available: http://findarticles.com/p/articles/mi_m0FCG/is_1_33/ai_n16118903/?tag=content;col1. (may 7, 2010).

Brown, K. (2003). From Teacher-Centered To Learner-Centered Curriculum: Improving Learning in Diverse Classrooms, Education, 124 (1), 49-54.

Gudep,V. (2007). Issues and Challenges in Academic Advising: A Multivariate Study of Students' Attitudes towards Academic Advising in United Arab Emirates (UAE). Contemporary Management Research. 3, 2, 151-172.

Hendey, W. (1999). Developmental Advising: A Practical View, The Mentor: an Academic Advising Journal, 1(1). $30-41$.

Isakson, R. \& Call, J. M. (1991). The freshman student and academic success: A counseling center's approach. Paper presented at the meeting of the American College Personnel Association, Atlanta, GA. (ERIC Document Reproduction, Service No. ED 334518).

Ismaiel, A.(1983).Responsibilities of Faculties toward University and Community. paper presented at the Faculties at Arab universities conference. King Soud University.

Komiya, N. Good, G. \& Sherrod, N. (2000). Emotional Openness as a Predictor of College Students' Attitudes. Journal of Counseling Psychology. 47, 1,138-143.

King, M. (1993). Academic Advising: Organization and Developing Services for Students. New York: Joss- Bss.

Komiya, N. Good, G. \& Sherrod, N. (2000). Emotional Openness as a Predictor of College Students' Attitudes. Journal of Counseling Psychology. 47, 1,138-143

Light, R. J. (2001). Making The Most Of College, Students Speak Their Minds, Cambridge, Harvard University Press.

Maxwell, M. (1979). Improving student learning skills. San Francisco: Jossey- Bass.

Nosanow, M. Hage,S. \& Levin, J. (2000). Group Intervention with College Students from Divorced Families. Journal of College Student Psychotherapy.14, 1, 43-59.

Rickinson, B. (1998). The Relationship between Undergraduate Student Counseling and Successful Degree Completion, Studies in Higher Education, 23, 1, 95-102.

Sahalwy, A. (1992).Characteristics of Faculties from Faculty of Education Students Perspectives. Journal of Education College. University of Qatar. 4. 17-32.

Whelley, T., Radtke, R., Burgstahler, S \& Christ, T. (2003). Mentors, Advisers, Role Models, Peer Supporters: Career Development Relationships and Individuals with Disabilities, American Rehabilitation, 27,1, 42-49. 
Table 1. The Study Population.

\begin{tabular}{|l|l|}
\hline Faculty & Total \\
\hline Engineering & 38 \\
\hline Science & 37 \\
\hline Education & 24 \\
\hline Administrative \& Financial Sciences & 15 \\
\hline Art & 21 \\
\hline Total & 135 \\
\hline
\end{tabular}

Table 2. The Distribution of the Study Sample According to the Faculty.

\begin{tabular}{|l|l|}
\hline Faculty & Total \\
\hline Engineering & 10 \\
\hline Science & 9 \\
\hline Education & 6 \\
\hline Financial and Administration & 4 \\
\hline Art & 5 \\
\hline Total & 34 \\
\hline
\end{tabular}

Table 3. Means and Std. Deviation for Staff Members Responses on the questionnaire

\begin{tabular}{|l|l|l|}
\hline Item & mean & Std. Deviation \\
\hline I follow up the academic schedule in each semester & 4.788 & .4151 \\
\hline I follow up the students achievement for different subjects & 3.7353 & 1.08177 \\
\hline I direct students to study particular subjects. & 4.0000 & .85280 \\
\hline I help students in every academic problem they face. & 4.1765 & .90355 \\
\hline I give adequate time for meeting my students whom I counsel & 3.4848 & 1.14895 \\
\hline I communicate with parents to solve the problems of their sons. & 2.1765 & .96830 \\
\hline I motivate students of high achievement. & 4.8182 & .39167 \\
\hline I prepare a special file for every student ( for his academic counseling) & 2.9091 & 1.56851 \\
\hline $\begin{array}{l}\text { I help students by solving their personal problems which may affect their academic } \\
\text { progress. }\end{array}$ & 3.5588 & 1.23561 \\
\hline I introduce counseling to students relating to their methods of study. & & \\
\hline I introduce counseling to students relating to their readiness for exams. & 4.2941 & .93839 \\
\hline I meet my colleagues to solve the problems of students & 4.0294 & 1.02942 \\
\hline I follow up all changes which take place on instructional programs. & 3.7941 & 1.03805 \\
\hline I investigate the reasons of withdrawals for the subjects that the students registered. & 4.5455 & .83258 \\
\hline I follow up the disqualified students for their absence. & 3.7353 & 1.02422 \\
\hline
\end{tabular}

Table 4. 2-WAY ANOVA for the Effect of College and Gender on the Degree of faculties' Practice towards students' academic counseling

\begin{tabular}{|l|l|l|l|l|l|}
\hline Source & Type III Sum of Squares & df & Mean Square & F & Sig. \\
\hline Corrected Model & $1.616 \mathrm{a}$ & 3 & .539 & 1.203 & .325 \\
Intercept & 381.657 & 1 & 381.657 & 852.363 & .000 \\
college & 1.499 & 1 & 1.499 & 3.347 & .077 \\
gender & .099 & 1 & .099 & .221 & .642 \\
college * gender & .459 & 1 & .459 & 1.024 & .320 \\
Error & 13.433 & 30 & .448 & & \\
Total & 517.322 & 34 & & & \\
Corrected Total & 15.049 & 33 & & & \\
\hline
\end{tabular}

